\title{
Contributions to the 2014 and 2015 flight pattern and damages of Carpomyia schineri Loew.
}

\author{
Erzsébet Voigt $^{1}$ - Dóra Kelemen ${ }^{2}-$ Miklós Tóth ${ }^{3}$ \\ ${ }^{1}$ Hungarian Horticultural Propagation Material Non-Profit Ltd., Budapest, Hungary \\ ${ }^{2}$ Research Institute of Fruit Production, Érd Research Station, Budapest, Hungary \\ ${ }^{3}$ Plant Protection Institute of HAS ARC, Budapest, Hungary \\ evoigt55@gmail.com
}

\begin{abstract}
SUMMARY
The fly Carpomyia schineri Loew is a pest of the berries of the feral Rosa canina group but is can also be found in the berries of grown rose cultivars. The larva damages the flesh of the berry, several larvae can develop inside a single berry. It can decrease the quantity and ascorbic acid content of the tea and jam, which are important human ascorbic acid sources during winter. At the same time in trapping experiments the adult can be confounded with adults of the walnut husk fly (Rhagoletis completa Cresson). In collections of berries at several sites in Hungary damage levels ranged from $0.88 \%$ to $65.08 \%$. Based on these damage levels we had the impression that the yellow sticky traps CSALOMON ${ }^{\circledR}$ PALz or PALs baited with the synthetic Rhagoletis lure caught moderate numbers of adults and were not satisfactory for detection, consequently improving trapping methods is necessary in the future.
\end{abstract}

Keywords: Carpomyia schineri flight dynamics, damage

\section{INTRODUCTION}

First records on the damage of Carpomyia schineri Loew. (Diptera, Tephritidae) from Hungary date back to 1947 from the arboretum of Horticultural University. Later (1953-1955) its presence was shown out also at the Budatétény plot of the Horticultural Research Institute. (Balás and Tóth, 1958). In recent years attention was drawn to the pest because in CSALOMON® ${ }^{\circledR}$ PALz traps set out to detect the quarantine walnut husk fly (Rhagoletis completa Cresson) single specimens of $C$. schineri were regularly recorded, and to the inexperienced eye the two species can easily be confounded (Orosz et al., 2012, Voigt et al., 2015). However, C. schineri damages only rose berries (Papp, 1994; Surányi, 2005; Surányi and Haltrich, 2006; Tuba, 2009). We were prompted on the one hand by the above to start a study on the biology and damages of $C$. schineri. On the other, rose berries (Rosa canina group, which includes several Rosa spp.) are an important source of ascorbic acid for humans. Dried berries are important for making tea, and the jam produced from berries is also preferred by many consumers, what is more, it is used also in wine making.

\section{MATERIALS AND METHODS}

In general CSALOMON® PALz (fluorescent yellow) traps with feeding attractant were used for monitoring the flight pattern. In studies on the effect of the addition of the feeding attractant CSALOMON® PALs (yellow) traps were used. As feeding attractant the described Rhagoletis lure containing ammonium salts was used (Tóth et al., 2004), which had been reported to be active in observations on several Rhagoletis spp. (Voigt and Tóth, 2008; Voigt et al., 2012; Tóth et al., 2014). Traps were suspended at the height of 1.0-1.5 m on rose bushes with ripening berries, and were inspected at 3-5 day intervals or weekly.

We selected first of all sites where Rosa canina group was part of the natural vegetation: i.e. Tétényi highland, Nadap, Telki, Pázmánd, Érd-Elviramajor, or Budatétényi Rózsakert in earlier studies. Berries collected were held in laboratory rearing dishes, larvae coming out and pupae were removed daily and were stored at $5^{\circ} \mathrm{C}$.

\section{RESULTS}

Damages of $C$. schineri could be recorded on all Rosa canina group bushes from which collection of berries was performed. It was reared out also from berries of cultivated tea-rose hybrids at the Budatétényi Rózsakert. Pupae obtained most probably belong to the taxon C. schineri; species verification will be possible after diapause from adults emerging next year.

The pest develops one generation per year, it overwinters as pupa in the soil, and adults swarm during the summer. According to some reports flight can start in June or July (Papp, 1994), others report the flight between end of July to middle of August (Tuba, 2009).

The place of egglaying on the berry is not easy to notice, however, the subsequent damage of the larva is clearly visible from the outside, a dark line appears along the feeding of the maggot. It feeds exclusively on the flesh, does not damage the seeds. Damage percentages are shown in Table 1 (Data collection closed at September 21, 2015). 
Damage levels of rose berries in 2015 at the different sites

\begin{tabular}{|c|c|c|c|c|c|c|c|c|}
\hline & $\begin{array}{c}\text { Érd- } \\
\text { Elvira } 2\end{array}$ & Nadap $^{2}$ & $\begin{array}{c}\text { Pázmánd } \\
1\end{array}$ & $\begin{array}{c}\text { Budatétény } \\
\text { Rózsakert }\end{array}$ & Sóskút & Telki & $\begin{array}{l}\text { Tétényi } \\
\text { fennsík }\end{array}$ & $\sum$ \\
\hline Size of berries (mm) & $\begin{array}{c}10-27 \\
x \\
6-16 \\
\end{array}$ & $\begin{array}{c}12-25 \\
x \\
9-19 \\
\end{array}$ & $\begin{array}{c}10-33 \\
x \\
7-18 \\
\end{array}$ & $\begin{array}{c}9-23 \\
x \\
7-15 \\
\end{array}$ & $\begin{array}{c}11-20 \\
x \\
7-16 \\
\end{array}$ & $\begin{array}{c}10-25 \\
x \\
6-12 \\
\end{array}$ & $\begin{array}{c}9-22 \\
x \\
5-16\end{array}$ & - \\
\hline $\begin{array}{c}\text { Total number of adults caught } \\
\text { (PALz trap+ Rhagoletis lure) }\end{array}$ & 31 & 44 & $\begin{array}{c}\text { no trap } \\
\text { operated }\end{array}$ & 14 & 10 & 0 & 9 & 108 \\
\hline Total of collected berries & 534 & 453 & 232 & 2052 & 339 & 502 & 1190 & 5302 \\
\hline Total of pupae & 35 & 291 & 151 & 334 & 3 & 40 & 194 & 1048 \\
\hline Damage level (\%) & 6.55 & 64.24 & 65.08 & 16.27 & 0.88 & 7.96 & 16.30 & 19.76 \\
\hline
\end{tabular}

1 Observations started later

2 PALs traps were used

In our previous observations on the flight in 2014 we established that the main flight took place first of all in August, although 3 adults were already caught at June 25 in PALz traps (Budatétény, Rózsakert). Flight was monitored at two sites: at Nadap (hedge, with one floral component of spp. of Rosa canina group), and Nagytétény -Rózsakert, where also several spp. of Rosa canina can be found. First adults were recorded at both sites at the very end of June, and the last ones in the first days of September. Already in 2014 we had the impression that the damage levels of berries was higher than expected on the basis of catch figures.

In 2015 traps were set out in the middle of June. Table 2 shows catch figures until the last inspection at September 22, from traps which were operated during the whole flight period.

Table 2

Beginning and end of flight of $C$. schineri in 2015

\begin{tabular}{|l|c|c|c|c|}
\hline & Set out date & $\begin{array}{c}\text { Date of first } \\
\text { catch }\end{array}$ & Date of last catch & Total caught \\
\hline Érd-Elvira & 30 June & 12 July & 20 September & 31 \\
\hline Nadap & 15 June & 8 July & 8 September & 44 \\
\hline Budatétény-Rózsakert & 22 June & 16 July & 8 September & 14 \\
\hline Telki & 1 August & - & - & 0 \\
\hline Tétényi highland & 5 August & 6 August & 2 September & 9 \\
\hline
\end{tabular}

In the course of the obervation period flight stopped or only single specimens were captured on the "high heat days" in 2015 at all observation sites.

As in our earlier studies the presence of the synthetic Rhagoletis feeding attractant significantly increased catches in yellow traps in three Rhagoletis spp. (Voigt and Tóth, 2008; Tóth et al., 2014), we set up an experiment with the objective of studying the influence of the addition of this lure on $C$. schineri catches. Observations were performed at Nadap and Érd-Elviramajor.

Results clearly showed that the addition of the lure significanlty increased catches also in C. schineri (Figure 1).

Despite the fact that traps with lures caught higher numbers, when comparing the relatively moderate catch figures with damage levels at the respective sites, we got the impression that CSALOMON ${ }^{\circ}$ PALz traps were relatively insensitive for catching $C$. schineri, and can be used for sensitive detection purposes only with reservations. 

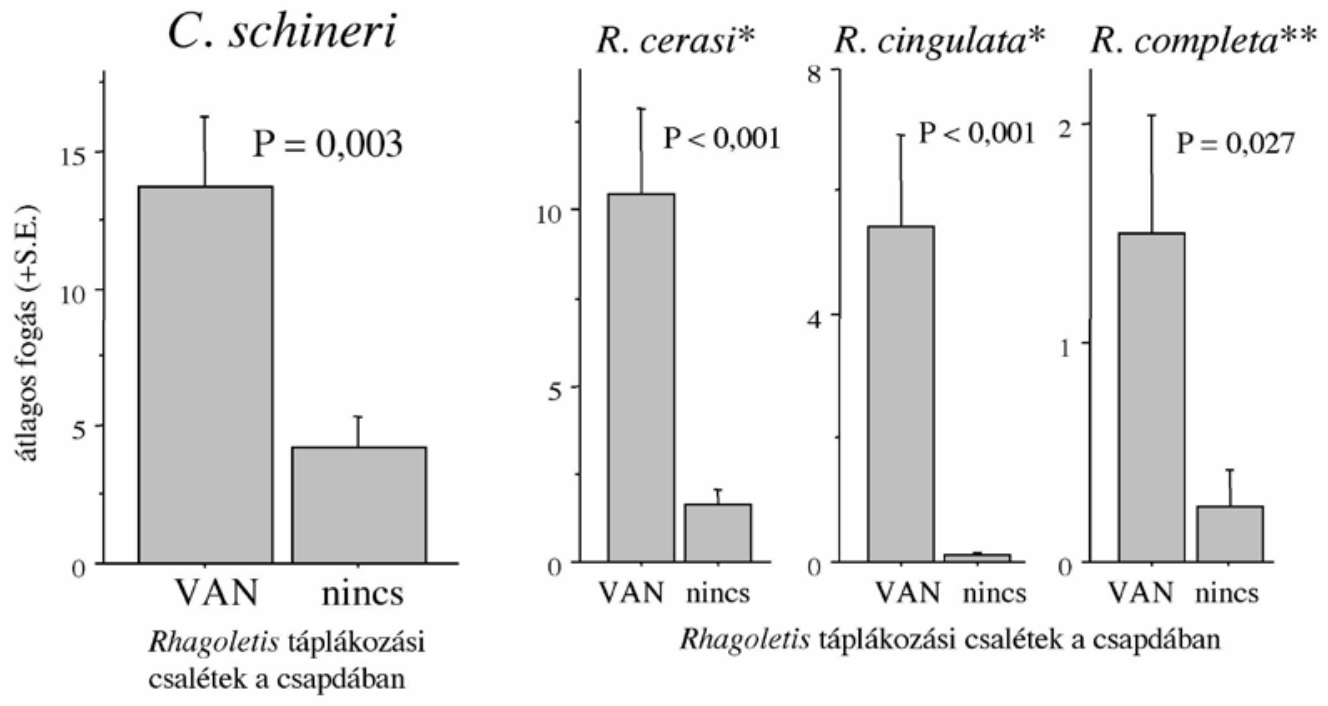

Total caught in test 144 flies. P values derive from Student $t$ test.

* after Voigt and Tóth, 2008; ** after Tóth et al., 2014.

\section{DISCUSSION}

Based on our preliminary results we can conclude that the main flight period of $C$. schineri takes place in August and beginning of September, in contrast to June and July mentoned in earlier literature. At this time berries already start to get red colouring. Traps available at this time (PALz and PALs) do not yield satisfactory performance, not even when combined with the Rhagoletis feeding attractant. They can be used for detection purposes (which is of utmost importance for harvest of berries) only with reservations. Running observations should be continued in 2016. Studies should concentrate among others on the correlation between the size of the berry and damage, and on sensitivity of different rose cultirvars.

\section{REFERENCES}

Balás, G. - Tóth, Gy. (1958): Adatok a fúrólegyek hazai elterjedésének és tápnövényeinek ismeretéhez. A Kertészeti és Szölészeti Főiskola Évkönyve. 22, 17-26.

Orosz, Sz. - Melika, G. - Krizbai, L. - Avar, K. - Lakosi, T. (2012): A nyugati dióburok-furólégy (Rhagoletis completa Cresson, 1929 Diptera: Tephritidae) 2012. évi hatósági felderítésének eredményei. XXIX. Integrált termesztés a kertészeti és szántóföldi kultúrákban Budapest, 2012 november 27. 37-45 pp.

Papp, L. (1994): Fúrólegyek. In. Jermy T. és Balázs K. (szerk.) A növényvédelmi állattan kézikönyve 5. Akadémiai Kiadó. Bp. 96 pp.

Surányi, D. (2005): A csipkebogyó-termesztést befolyásoló rovarok. Diplomamunka. Budapesti Corvinus Egyetem. Kertészettudományi Kar. Rovartani Tanszék. Budapest.

Surányi, D. - Haltrich, A. (2006): A csipkebogyó-termesztést befolyásoló rovarok. 52. Növényvédelmi Tudományos Napok elöadásainak és posztereinek összefoglalója. $91 \mathrm{pp}$.

Tóth, M. - Szarukán, I. - Voigt, E. - Kozár, F. (2004): Hatékony cseresznyelégy- (Rhagoletis cerasi L., Diptera, Tephritidae) csapda kifejlesztése vizuális és kémiai ingerek figyelembevételével. Növényvédelem. 40, 229-236.

Tóth, M. - Voigt, E. - Baric, B. - Pajac, I. - Subic, M. - Baufeld, P. - Lerche, S. (2014): Importance of application of synthetic food lures in trapping of Rhagoletis spp. and Strauzia longipennis Wiedemann. Acta Phytopath. Entomol. Hung. 49, 25-35.

Tuba, K. (2009): Adatok három gyümölcslégyfaj Vas megyei előfordulásához. Növényvédelem 45, 491-495.

Voigt, E. - Tóth, M. (2008): Az amerikai keleti cseresznyelegyet és az európai cseresznyelegyet egyaránt fogó csapdatípusok. Agrofórum 19, 70-71.

Voigt, E.. - Subic, M. - Baric, B. - Parac, I. - Tóth, M. (2012): A szintetikus táplálkozási csalétek fontossága gyümölcskárosító fúrólegyek (Rhagoletis spp.) csapdázásában. Agrofórum Extra 43, 82-86. 
Voigt, E. - Lengyel, G. - Markóné Nagy, K. - Károlyi, M. - Tóth, M. (2015): A célkártevővel összetéveszthető légyfajok a Rhagoletis csalétekkel felszerelt CSALOMON® PALz csapdákban. 61. Növényvédelmi Tudományos Napok előadásainak és posztereinek összefoglalója, 83 pp. 